\title{
Mapping Creative Industries in the Zlin Region
}

\author{
Bednár Pavel, Grebenícek Pavel
}

\begin{abstract}
Mapping of creative industries is a crucial basis for assessing the creative economy in regions. It ensures the development of creative clusters and the subsequent identification of stakeholders and networks. The present approach is to transfer creative industries research from global cities and urbanized old industrial regions to peripheral rural regions, in our case with preserved ethnographic traditions and crafts and tradition in design and film production which forms the core activities of the region. The article discusses the methods of secondary data quantitative analysis of the commercial creative industries from publicly available sources and reveals shortcomings in databases in the Czech Republic. The mapping takes into account the contribution of time factor within the definition of the creative industries segments, where it reveals significant differences not only between them but also, it shows differentiation between enterprises with employees and non-employing enterprises. The article serves as a foundation for the facilitation of creative clusters and creative industries development strategies as instruments that support competitiveness at the regional level.
\end{abstract}

Key words: creative region, creative industries, mapping, Zlin Region

\section{INTRODUCTION}

There have not yet been taken too many steps towards the analysis of creative industries at the regional level in the Czech Republic. Among the key contributions, we considered Rumpel, Slach \& Koutský (2010) dealing with the spatial perspective of creative industries in the Moravian-Silesian Region and Jirčíková (2009) addressing the theory of mapping using the Creative Trident methodology, including its application at the national level. The remaining authors (Cikánek, 2009; Kloudová et al., 2010) focus on the introduction to creative industries in the Czech Republic where the main aims are the definition of creative industries, creative class, creative index, management issues and an evaluation of creative economy's impact.

Following the previous studies and in order to further research the creative industries in the Czech Republic, the question of methodical unification of mapping the creative industries arises to ensure the provision of a robust process. In terms of national conditions, however, this is hindered by a weak data base limiting research exclusively to a sector approach, i.e., mapping the creative industries firms rather than creative occupations. In addition to this level, there have occurred some fundamental differences in relation to available data sources in terms of distinctions of the creative industries to commercial, public and informal sector (UNCTAD, 2010; Wiesand \& Söndermann (as cited in Kloudová, 2009; Kloudová et al., 2010)).

The public sector in the creative industries has both the database of organizations with regular reporting and also publicly available statistical yearbooks (see NIPOS-CIK, 2011). A forth- 
coming database of NGOs with a cultural focus, registered at the Ministry of the Interior of the Czech Republic under Act No. 83/1990 Coll. (see NIPOS-CIK, 2011), will provide a support for mapping the informal sector in the creative industries. The creative industries within the commercial sector are in a completely opposite situation. There is neither a specialized database publicly available nor a methodology covering this sector. A comprehensive database of the Business Register (RES) of the Czech Statistical Office (CSO) or the Administrative Business Register (ARES) of the Ministry of Finance of the Czech Republic are the only publicly available sources of secondary information about commercial creative industries, which provide data on the given economic entity from all registers kept by the state administration. A commercial search software containing databases of Creditinfo-Firemní monitor is the last secondary source of information on the creative industries business sector in the Czech Republic. It uses all publicly available registers as data sources, including registers of tax authorities and other commercial databases. The paper offers insight into the realm of creative industry in the rural peripheral region with a significant level of entrepreneurial activity per 1,000 economically active inhabitants (i.e., 467 enterprises) and the urban centre based on light industry.

This paper is primarily to develop approach in Rumpel et al (2010) and to offer additional methods for evaluating commercial creative industries in the Czech Republic. The paper also offers insight into the realm of creative industry in the rural peripheral region with significant level of entrepreneurial activity per 1,000 inhabitants and the urban centre based on light industry.

Thus the aim of the paper is to improve the discussion on methodology for data collecting and analysis within the creative industries mapping at the regional level using secondary dataset. Nevertheless, the major objective is to map the creative industries at the regional level, including both core and peripheral areas in favour of the future preparation of micro-regional development strategies focused on the creative industries (Jayne, 2005). The development of creative industries in the region subsequently maintains or increases the number of individuals in the creative class, who are supposed to pay more attention to amenities and the quality of space in social, physical and functional terms, i.e. 'soft' location factors in terms of debate on the competitiveness of regions (Bontje \& Musterd, 2009). The Zlín Region is selected for the analysis, with respect to traditional creative industries of the local economy, i.e., film production, design, and glass industry (see e.g., Bell \& Jayne, 2003; Jayne, 2004).

\section{THEORETICAL SOLUTIONS}

Mapping the creative industries plays a key role in assessing the position of creative industries in the economy (Higgs \& Cunningham 2007; Higgs \& Cunningham, 2008; Higgs, Cunningham $\&$ Bakhshi, 2008) at any spatial level and particularly during facilitation of creative clusters (Lazzeretti, Boix \& Capone, 2008). Furthermore, the mapping of creative industries faces many difficulties in terms of their definition, methods of collecting information, availability of secondary databases, and the way of interpreting the results of the data processing. The mapping of creative industries is conducted at different spatial levels - global, national, and regional and, last but not least, city or local levels, respectively.

The following methods belong among quantitative methods of mapping creative industries 
revealing their structure and spatial distribution (Higgs \& Cunningham, 2008; Higgs et al., 2008):

- mapping the creative industries by the industry activity-based on segment definitions,

- mapping creative industries by occupations (see e.g. Markusen et al., 2008).

In the first case, according to Higgs and Cunningham (2008), the research focuses on:

- Firm activity - primarily the number of firms, the full time employees, sometimes banded according to their turnover and occasionally the degree of concentration of the industry,

- Gross value add to the economy determined by national input/output tables or specialist surveys,

- Exports - the value of exports from the industry usually determined by both survey and extrapolation or from official product and service export statistics. (p. 8)

The industry segment of activity-based definitions, however, does not respect the relationship to the value chain within the creative industries (Higgs \& Cunningham, 2008). This may be the case when translating activities are part of the core value chain (a translation of a book as a work of art), which is supported by pre-press preparation and printing, or when the translation is considered an activity that facilitates the distribution of autonomous supporting activities (a translation of a manual for the use of specialized design software).

The second case involves the mapping using the Creative Trident method. 'The model brings together those working in the creative industries and working in specialist creative jobs in other firms and organisations' (Higgs et al., 2008, p. 3). We focus on three types of employment:

- creative occupancies in creative industries,

- support staff in creative industries providing management, secretarial, administrative or accountancy back-up,

- creative individuals 'embedded' in other industries not defined as 'creative'.

Collectively, they are the creative employments. Creative occupations in creative industries and individuals 'embedded' in other industries not defined as 'creative' then together form a core of the creative class (Florida, 2002). The problem in mapping the occupations in creative industries consists of cases where, e.g., a design firm employee also has a work contract with a non-governmental organization engaged in a creative sector.

\section{OBJECTIVES AND METHODOLOGY}

Since the aim of the paper is a case study on differentiation and spatial distribution of regional creative industries firms, the mapping was done at the administrative territories of municipalities with extended powers (MEP) despite the concentration of creative industries in cities (e.g., Desrochers \& Leppälä, 2011; Prat, 2008). Having regard to the settlement structure of the region, its peripheral location and rural character of the Slovakian border areas, the abovementioned method of mapping was implemented following the examples of Bell and Jayne, 2010; Jayne, 2005; Waitt and Gibson, 2009; White, 2010. The creative industries commercial firms mapping was based on Wiesand and Söndermann (as cited in Kloudová, 2009; Kloudová et al., 2010) using a secondary database of Creditinfo-Firemní monitor 2010, summarizing data from the ARES system. This database provides an advantage of the definition of the item of 
'Predominant CZ NACE' enabling to avoid the double-counting of firms within the creative industries. Thus every company is unambiguously assigned to a particular segment of the creative industries. As a result, the following variables from the database of Creditinfo-Firemní Monitor 2010 were selected:

- firm name,

- type of ownership,

- firm size by number of employees broken down in categories by number of employees,

- registered office showing the municipality and the administrative territory of MEPs,

- date of firm registration, enabling to derive the length of trading

- Further items were not selected for the following reasons:

- turnover - incomplete data with non-employing enterprises; various time periods of data sources

- export - incomplete data with non-employing enterprises; various time periods of data sources; export destination not spatially differentiated.

The companies which had been declared insolvent were removed from the collected database not being involved in any corresponding activities in relation to the creative economy. Predominant CZ NACE sectors of creative industries firms were clustered with respect to Wiesand and Söndermann (as cited in Kloudová, 2009; Kloudová et al., 2010) and the distribution of the length of trading. This resulted in the determination of the 'Derived predominant CZ NACE' variable containing thirteen creative industries segments. With regard to the structure of creative firms in the Zlín Region and according to their size, i.e., an insignificant number of medium-sized enterprises with 50 to 250 employees, firms were divided to two different categories, enterprises with employees and non-employing enterprises, where the differences were detected not only in their spatial distribution and structure but also in the length of trading.

\section{RESULTS}

The total of 4951 firms was revealed as the result of creative industries mapping procedure in the Zlín Region. The proportion of non-employing enterprises reached 86.6\%. The predominant percentage of non-employing enterprises corresponds to the findings in Baines and Robson, 2001, as many sectors of creative industries do not require a considerable initial capital or office space for starting a business. A major finding in terms of the size of enterprises with employees is the absence of large companies over 250 employees. Thus creative enterprises with employees (663) in the Zlín Region consist exclusively of micro (578; 87.2\%) and small enterprises $(70 ; 10.6 \%)$ and medium-sized enterprises $(15,2.2 \%)$ in accordance to the European Commission Recommendation 2003/361 regarding the small and medium-sized enterprises definition.

The assessment of the role played by commercial creative industries in the Zlín Region can be supported by two variables where the variable 1 is the proportion of creative industries firms on the total number of firms $(3.4 \%)$ in the region and variable 2 is the proportion of workers employed in creative industries firms to the total number of employees in the region $(3.3 \%)$. The determination of the estimated number of workers employed in creative industries firms 
was based on the conversion of the categorized number of employees to the median number of employees followed by the calculation of the proportion of the total workers employed in creative industries firms to the total number of employees of firms in the Zlín Region.

A detailed overview of the creative industries and entreprises with employees in the Zlín Region by sector is presented in Table 1 . The low proportion of architectural firms might be explained by the absence of the particular university degree programme in the region, limited demand compared to urbanized regions with cities over 100,000 inhabitants and strong competition in major urban agglomerations in the Czech Republic, namely Brno, Ostrava and Prague. The reasonable reputation and tradition is also a prerequisite for successful market presence in the field of architecture. Large scale projects require more collaboration of firms solving partial subtasks, thus there is a need for proximity of suppliers providing face to face contacts. The complexity of architectural activities is also reflected by the prevalence of enterprises with employees over non-employing enterprises, which is an exception among the other sectors of creative industries in the Zlín Region.

It is considered that the low proportion of motion picture and video firms in the Zlín Region's creative industries sector is because of the necessity of excellent knowledge of the limited market, higher costs of technical equipment and trained personnel, wider scope of knowledge compared to music production and lack of proximity of customers primarily for the enterprises with employees. In contrast, non-employing enterprises are expected to focus predominantly on the regional customers. The abovementioned assessment of the proportion of motion picture and video firms might also be applied to broadcasting and news agency firms requiring a large information base and expensive electronic equipment, especially in the case of radio and television.

Tab. 1 - Creative industries by type of businesses in the Zlín Region. Source own calculation based on Creditinfo - Firemní monitor 2010

\begin{tabular}{|l|c|c|c|c|c|c|}
\hline \multirow{2}{*}{$\begin{array}{l}\text { Derived Predominant } \\
\text { CZ NACE }\end{array}$} & \multicolumn{2}{|c|}{$\begin{array}{c}\text { Eusinesses in creative Industries } \\
\text { empleyses with }\end{array}$} & $\begin{array}{c}\text { Non-employing } \\
\text { enterprises }\end{array}$ & \multicolumn{2}{c|}{ Total } \\
\cline { 2 - 7 } & $\begin{array}{c}\text { No. of } \\
\text { businesses }\end{array}$ & Percent & $\begin{array}{c}\text { No. of } \\
\text { businesses }\end{array}$ & Percent & $\begin{array}{c}\text { No. of } \\
\text { businesses }\end{array}$ & Percent \\
\hline Architecture & 23 & $3.5 \%$ & 11 & $0.3 \%$ & 34 & $0.7 \%$ \\
\hline $\begin{array}{l}\text { Motion picture and } \\
\text { video }\end{array}$ & 8 & $1.2 \%$ & 41 & $1.0 \%$ & 49 & $1.0 \%$ \\
\hline $\begin{array}{l}\text { Sound recording and } \\
\text { music publishing }\end{array}$ & 27 & $4.1 \%$ & 203 & $4.7 \%$ & 230 & $4.6 \%$ \\
\hline Photography & 21 & $3.2 \%$ & 199 & $4.6 \%$ & 220 & $4.4 \%$ \\
\hline $\begin{array}{l}\text { Translation and inter- } \\
\text { pretation }\end{array}$ & 24 & $3.6 \%$ & 940 & $21.9 \%$ & 964 & $19.5 \%$ \\
\hline Pre-press services & $24 \%$ & 195 & $4.5 \%$ & 219 & $4.4 \%$ \\
\hline
\end{tabular}




\begin{tabular}{|l|c|c|c|c|c|c|}
\hline $\begin{array}{l}\text { Software publishing, } \\
\text { data processing and } \\
\text { web portals }\end{array}$ & 189 & $28.5 \%$ & 1137 & $26.5 \%$ & 1326 & $26.8 \%$ \\
\hline $\begin{array}{l}\text { Advertising and mar- } \\
\text { ket research }\end{array}$ & 176 & $26.5 \%$ & 962 & $22.4 \%$ & 1138 & $23.0 \%$ \\
\hline $\begin{array}{l}\text { Broadcasting and } \\
\text { news agencies }\end{array}$ & 6 & $0.9 \%$ & 3 & $0.1 \%$ & 9 & $0.2 \%$ \\
\hline Specialised design & 5 & $0.8 \%$ & 26 & $0.6 \%$ & 31 & $0.6 \%$ \\
\hline $\begin{array}{l}\text { Creative, arts and } \\
\text { entertainment }\end{array}$ & 14 & $2.1 \%$ & 107 & $2.5 \%$ & 121 & $2.4 \%$ \\
\hline $\begin{array}{l}\text { Publishing of pe- } \\
\text { riodicals and other } \\
\text { publishing }\end{array}$ & 73 & $11.0 \%$ & 174 & $4.1 \%$ & 247 & $5.0 \%$ \\
\hline Publishing of books & 73 & $11.0 \%$ & 290 & $6.8 \%$ & 363 & $7.3 \%$ \\
\hline Total & 663 & $100.0 \%$ & 4288 & $100.0 \%$ & 4951 & $100.0 \%$ \\
\hline
\end{tabular}

Generally, translation and interpretation firms are characterized by low cost of entry to the industry, focus on learning the English, German and French language and the increased need for communication with foreign countries after 1989 related to the release of political and economic barriers to international trade or doing business abroad.

The high proportion of software publishing, data processing and web portals, advertising and market research firms is caused, in the former case, by rapid IT development and its affordability to households and introducing appropriate fields of study at high schools, colleges and universities, in the latter case, due to the transition from a centrally planned economy to a market economy after 1989 and thus the need for firms to know the market requirements and promote their products.

Moreover, the Faculty of Multimedia Communications of the Tomas Bata University in Zlín established in 2002 has been generating a local skilled workforce for this segment of the creative industries, supported by the traditions of marketing activities originated in the period of the Bata shoe manufacturing company in the centre of the region.

The low proportion of specialised design firms is startling despite the presence of companies in the plastic industry, precision engineering, furniture, household goods and footwear. It is necessary to emphasize the lack of key regional customers of industrial design in terms of clothing or automotive industry or, conversely, the gradually declining glass industry in the north-eastern part of the Zlín Region. Nonetheless, the field of industrial design is considered to be sensitive to the protection of patent rights and industrial designs and therefore we expect secondary industries firms to employ own professional designers who, based on the selected methodology and data availability, could not be classified among the companies of creative industries.

The reason behind the low number of businesses in creative arts and entertainment activities lies in the need of a sufficiently large market with adequate purchasing power and available finances, since spending on entertainment and the arts are among the first restricted by house- 
holds during the economic decline. Moreover, firms in this field of creative industries in the Zlín Region are supplemented by almost 250 public institutions (museums, libraries, theatres and cultural centres) and NGOs dealing with, in particular, traditional art (folklore ensembles, choirs and dance groups) or associating independent artists (sculptors and painters, etc.).

Figure 1 indicates the concentration of firms in the creative industries segments in MEPs by employment in the Zlín Region. More significant concentrations prevail in enterprises with employees corresponding to the importance of the Zlín MEP as a core area in the Zlín Region and representing it as the natural political, economic, educational and cultural centre of the region with all urbanization effects (see Rumpel et al., 2010). The concentration of creative industries enterprises with employees in the Zlín MEP includes the following:

- architectural firms and pre-press services firms preferring localization in the most distinctive concentration of customers, i.e. the existence of considerable catchment area,

- motion picture and video and specialised design firms built on the tradition of Bata company, opportunities for studying these fields at the local college and university and local creative milieu,

- broadcasting and news agency firms requiring the best possible access to information and their concentration in decision making centres,

- creative, arts and entertainment firms preferring localization in the most distinctive concentration of customers, i.e. the existence of considerable catchment area along with creative milieu and local buzz,

- publishing of books, periodicals and other publishing firms preferring localization in the most distinctive concentration of customers here in terms of proximity along with the presence of a creative milieu and local buzz.

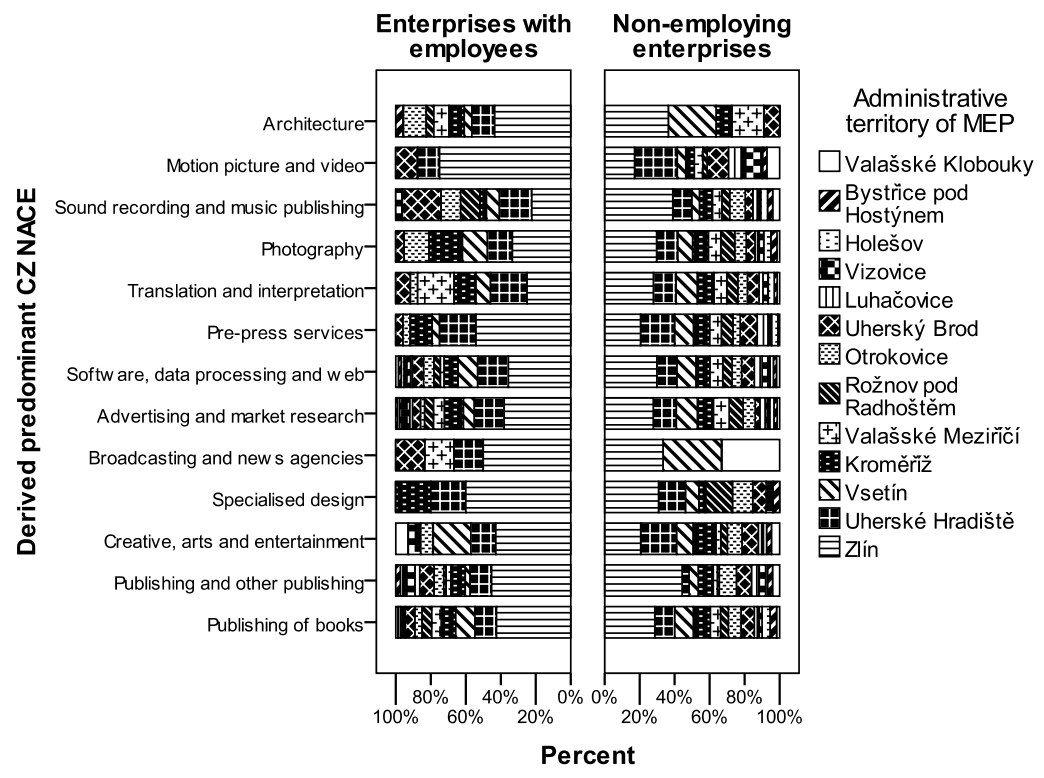

Fig. 1 - Creative industries by type of businesses and by administrative territories of MEP in the Zlin Region. Source: own calculation based on Creditinfo - Firemni monitor 2010 
The remaining creative sectors within enterprises with employees are either tied to local markets (photographic firms), or the existence of a large market without customers in the proximity is sufficient for their presence, because their products are easily redistributable via electronic communication, or are subcontracted by more extensive projects (such as sound recording and music publishing firms, translation and interpretation firms).

The concentration of the non-employing enterprises in creative industries in the Zlín MEP is not so significant and the proportion reaches one third on average in all segments except publishing of periodicals preferring localization in the most distinctive concentration of customers in terms of proximity. The concentration of motion picture and video firms and the creative arts and entertainment firms in the Uherské Hradiště MEP might be derived from an annual non-competition film event, the 'Summer Film School', the largest one in the Czech Republic, i.e., from creative milieu and local buzz, in the former case, and the traditional role of Uherské Hradiště as a centre of local folk culture supported by the importance of the Theatre of Moravian Slovakia in the cultural development of both the given MEP and the southern part of the Zlín Region thus also through creative milieu, in the latter case.

Figure 2 was drawn using the multidimensional scaling through the ALSCAL method which enables spatial measurements using Euclidean distances plotting the similarity of cases based on proportion (Garson, 2009) of the creative industries segments in the MEPs of the Zlín Region. When interpreting the results of the graph, the most similar cases are those located in close proximity. With increasing distance between the cases of both dimension 1 and dimension 2, the degree of their similarity in the proportion of shares of individual sectors in the creative industries decreases. The presentation of results conducted under this method was performed for non-employing enterprises only, because the analysis of enterprises with employees in the MEPs of the Zlín Region reveals a similar structure as found out at the regional level. The structure is affected only by those MEPs with a few segments of the creative industries and urban centres with local importance in peripheral areas of the region, i.e., Bystřice pod Hostýnem, Holešov, Luhačovice, Rožnov pod Radhoštěm, Valašské Klobouky and Vizovice. 


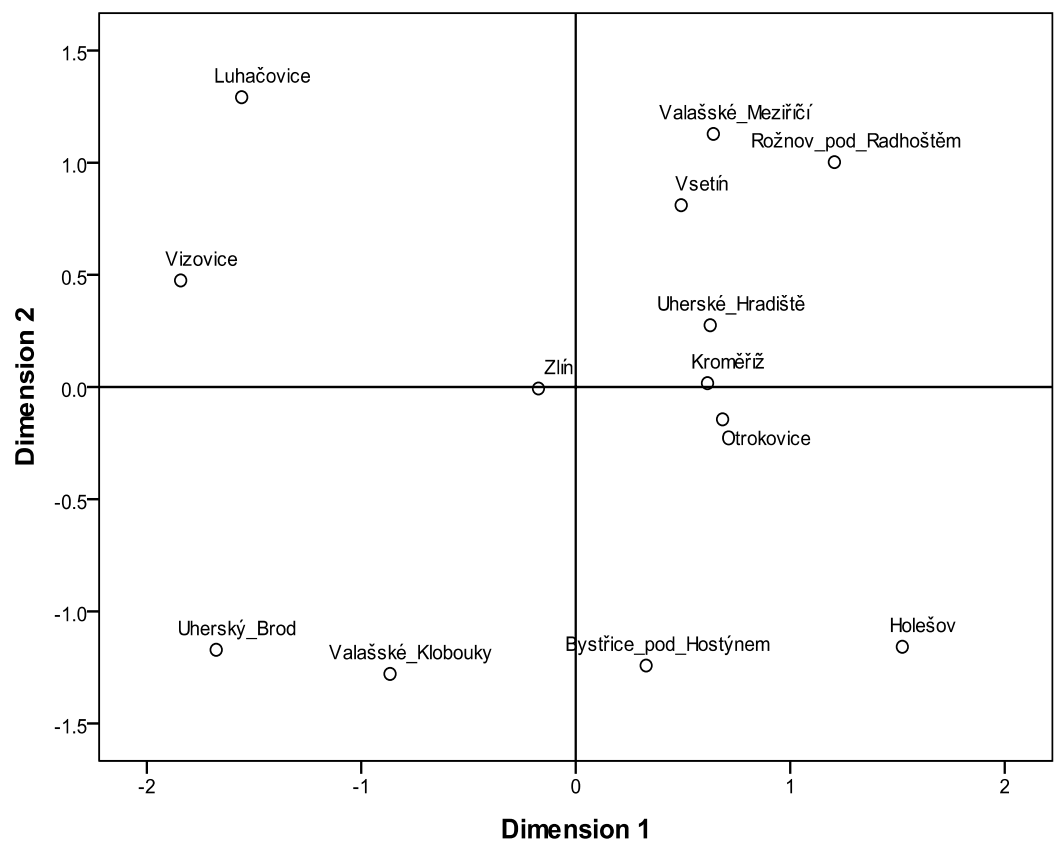

Fig. 2 - Administrative territories of MEP by creative industries in the Zlin Region. Source: own calculation based on Creditinfo - Firemni monitor 2010

The two-dimensional graph provides the most significant solution for similarity of the MEPs by the structure of non-employing enterprises in the creative industries. The Zlín MEP was plotted in the centre because of the highest proportion of non-employing enterprises in the region with a similar representation of creative industries segments. The cluster of Uherské Hradiště, Kromeř́ž and Otrokovice is represented by MEPs along the Morava River in the western part of the region with a higher proportion of the creative arts and entertainment compared to the Zlín MEP. In the case of the Uherské Hradiště and Kromeříž MEPs, we presume the relation to the historical development of particular administrative centres as a place for performing cultural and religious activities in the region. The role of local cultural house, good transport connections and the borders of three ethnographic regions of Haná, Moravian Slovakia and Moravian Wallachia seem to be a probable explanation for the Otrokovice MEP. The Uherské Hradiště MEP shows the highest proportion of pre-press services (7.1\%) between the MEPs in the Zlín Region and the lowest proportion of publishing of periodicals and other publishing firms $(1.3 \%)$ vice versa, which may indicate a unique position of the enterprises with employees in this segment.

The 'Moravian Wallachia creative industries core cluster' in the north-eastern part of the peripheral region reached the lowest proportion in the sound recording and music publishing, and also in the publishing of periodicals and other publishing non-employing enterprises (1$2 \%$ among the MEPs in the Zlín Region. On the other hand, this cluster holds a leading position in the proportion of advertising and market research firms (28\%). 
The eastern hinterland of the MEP Zlín formed by the Luhačovice and Vizovice MEPs similarly to the 'Moravian Wallachia core cluster' indicates low proportions in sound recording and music publishing firms. Conversely, these MEPs are featured by the highest proportion of nonemploying enterprises in software publishing, data processing and web portals (36\%). It seems reasonable to assume that information technologies play a crucial role in the involvement of hinterland of urban centres (i.e., urban-rural fringe) in the creative economy.

The Zlín MEP together with the eastern and western hinterland (i.e., the Otrokovice MEP and the Luhačovice and Vizovice MEPs respectively) are characterized by the highest proportion of periodicals publishing and other publishing non-employing enterprises in the Zlín Region $(5 \%)$, which supports the theory of presence of this creative industry segment in core areas with a significant concentration and close proximity to customers, primarily in advertising materials such as flyers, advertising and corporate newspapers.

The southeast frontier cluster formed by the Uherský Brod and Valašské Klobouky MEPs demonstrates the lowest percentage in the advertising and market research $(9.9 \%$ and $17.1 \%$ respectively), which corresponds to their peripheral location. Maintaining the traditional role of folk arts and crafts and a low degree of urbanization in these MEPs is manifested by the supreme proportion of non-employing enterprises in the creative, arts and entertainment segment in the Zlín Region (3.8\% and 6.1\%). Furthermore, the peripheral location of the frontier Valašské Klobouky MEP is proven by the lowest percentage of pre-press services firms in the region. On the other hand, the highest proportion in the sound recording and music publishing non-employing enterprises in the Valašské Klobouky MEP might be derived from the development of information technologies, acquiring music online, low cost rental office spaces, setting recording studios in own dwelling and, last but not least, artistic traditions of Moravian Wallachia. The Luhačovice and Valašské Klobouky MEPs present themselves with the lowest percentage of translation and interpretation firms. We suppose that this proportion is determined by the absence of towns with more than 10,000 inhabitants, out-migration of linguistically educated population and in the case of the Valašské Klobouky MEP it is linked with the peripheral location and thus the distance from the core urban centres in the region with concentration of economic activities requiring intensive communication with other countries with the exception of the Slovak Republic owing to the similarity of both languages. The last cluster refers to the Bystřice pod Hostýnem and Holešov MEPs located in the western peripheral part of the region at the transition between the Moravian Vales and the Hostýnské Mountains containing two micro centres with a population of 10,000. Moreover, a potential local creative class may comfortably out-migrate or commute into the surrounding major urban centres (Přerov, Olomouc and Zlín), which results in the concentration of non-employing enterprises to several sectors, most notably translation and interpretation activities and publishing of books, corroborating the above average values in the Zlín Region. Furthermore, in both MEPs below-average values were exposed in advertising and market research and the lowest percentage of the software publishing, data processing and web portal firms (18.1\%) was ascertained in the Holešov MEP.

The histogram (Figure 3) reveals a uniform distribution of the length of trading in creative non-employing enterprises. On the contrary, the frequency of non-employing enterprises' registration is tied to the economic cycle at the global level, technological advances in IT and 
systemic political and partially demographic changes at the national level. The first phase of non-employing enterprises' in growth, with the concentration in 1989-1991, aroused after the systemic changes allowing private entrepreneurship. The high frequency of firms being active since the beginning of the 90 s of the 20th century implies their success in the market or an attempt of individuals to maintain the status of entrepreneur.

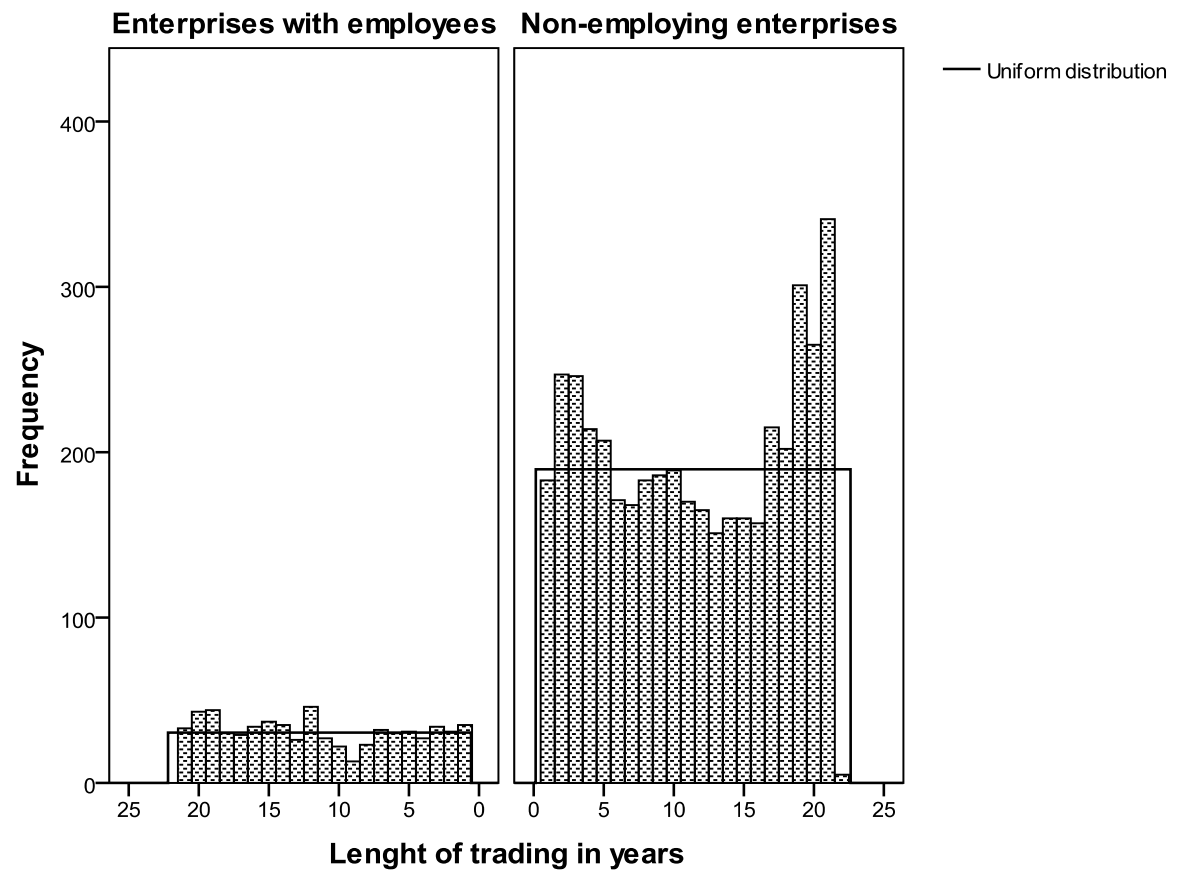

Fig. 3 - Length of trading for creative industries in the Zlin Region. Source: own calculation based on Creditinfo - Firemni monitor 2010

The second phase of a noticeable growth during 2000-2003 might be associated both with advancements in IT (particularly availability along with affordability of the Internet and other (portable) electronic devices such as computers, laptops, printers and backup media - CD and DVD), and commencement of the demographically distinct university-educated population of the 70 s of the 20th century. The third phase was portrayed by a striking growth in 2005-2009 and it was given primarily by the expansion phase of the business cycle at the global level, which was positively reflected in the Czech Republic. The fall of non-employing enterprises establishment at the turn of 2009 and 2010 is associated with the beginning of the economic recession and therefore a lower willingness of individuals to start an enterprise, risk of low demand, risk of insolvency of bank loans to name but a few.

A box plot (Figure 4) was used to evaluate the differences between the creative industries segments by the type of businesses in creative industries in relation to the length of trading in years. The 'length' box is the interquartile range. The outlier cases represent cases with values between 1.5 and 3 of the box lengths from the upper or lower edge of the box. The extreme 
cases are those with values more than 3 of the box lengths from the upper or lower edge of the box. As a result, every part of the graph represents a quarter of all the values of the length of trading in years in the particular segment of the non-employing enterprises and enterprises with employees.

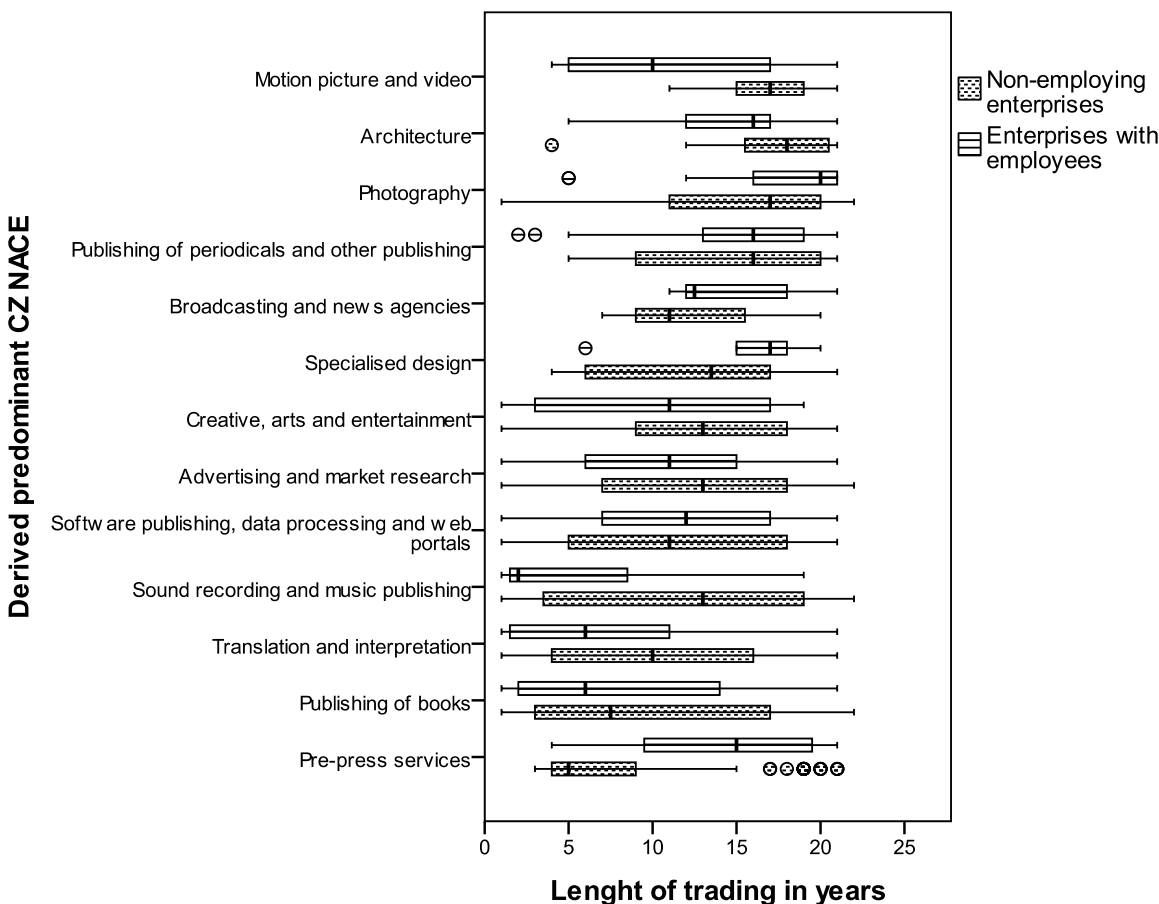

Fig. 4 - Length of trading by creative industries segments in the Zlin Region. Source: own calculation based on Creditinfo - Firemni monitor 2010

A ranking of the creative industries segments in the graph was performed from the segments with a predominance of the long-trading firms over the segment dominated by the start-up firms. Hence we derive three basic types of creative industries segments in the Zlín Region by the length of trading in years:

- aging segments - motion picture and video, architecture, photography, publishing periodicals and other publishing, broadcasting and news agencies, specialised design

- stagnant segments - creative, arts and entertainment, advertising and market research, software publishing, data processing and web portals

- emerging segments - sound recording and music publishing, translation and interpretation, publishing of books, pre-press services.

The aging segments with no difference according to the employment are determined by either a difficult entry to the market in the sector (i.e., tough competition or limited regional market) - architectural firms, broadcasting and news agency firms, specialised design firms - or devel- 
opment and affordability of digital and browsing technologies for households - photographic firms, publishing periodicals and other publishing firms. The emerging creative industries segments, i.e., with the lowest medians of the length of trading, include publishing of books and translation and interpretation firms. In the first case, the expansion might be related to both computerized typesetting, press and selling books on-line and increased demand for publications, conference proceedings, company brochures and many others. In the latter case, growth of translation and interpretation firms may be linked to deepening integration of the regional economy into the global market economy and also maturation of the generation equipped with internationally recognized language certificates and experiences with internships abroad. A nested generalized linear model assuming multinomial distribution with a cumulative logit link function was employed to examine the differences in the length of trading in years between non-employing enterprises and enterprises with employees for each segment. The following differences between the segments of the creative industries by type of businesses in creative industries were observed:

- Motion picture and video - The new enterprises with employees are likely to set up either as a long term consequence of making movies by foreign studios in the Czech Republic or due to implementing film production into education in the specialized institutions in Zlín (i.e., Tomas Bata University in Zlín and Film College Zlín). The new technological and societal challenges also include the need for digitalisation of contents and which creates a future potential for the Zlin audiovisual industry. Conversely, the non-employing enterprises face both difficulty of entry to a limited regional market and advances in IT technology and audiovisual equipment while enables of acquiring quality films by either individuals and companies production.

- Sound recording and music publishing - The rapid establishment of non-employing enterprises in the 90 s of the 20 th century is associated with the permission of private entrepreneurship and advancements in digital recording. The formation of current enterprises with employees tied up to the expansion of the broadband and mobile Internet, thus reducing distribution costs, i.e., online music stores, music streaming services and internet radios.

- Pre-press services - We put the growth of non-employing enterprises into the context of computerized typesetting, printing and selling books online.

\section{DISCUSSION}

From a methodological perspective, the paper revealed the validity of treatment of a continuous derived variable for the length of trading compared to its division into categorical variable (see Bell \& Jayne, 2010; Rumpel, Slach \& Koutský, 2010). The continuous variable enabled evaluation of the length of trading with respect to economic cycles, systemic policy decisions and demographic trends. A similar percentage of employment in enterprises with employees to the total number of non-employing enterprises in the Zlín Region (3.3\%) was achieved as in the case of the Western Region of Ireland (White, 2010). The results confirm the weak position and low proportion of creative industries in the region's periphery and their concentration in the core areas along with a predominant presence of non-employing enterprises and micro enterprises with up to 10 employees (Baines \& Robson, 2001). The equal findings were revealed 
in the length of trading in several creative industries segments in the Zlín Region compared with the data from the English county of Shropshire in the UK (Bell \& Jayne, 2010), i.e., in the aging segments - notably architecture, broadcasting and news agencies and publishing periodicals and other publishing - and in the stagnant segments - creative, arts and entertainment.

\section{CONCLUSION}

Based on the administrative definition of the MEP, differences were discovered between core and peripheral areas in the region. The orientation towards creative industries segments with the existence of considerable catchment area was found in the peripheral areas, particularly in enterprises with employees. Thus two segments, i.e., software publishing, data processing and web portals and translation and interpretation make predominant contribution to the deconcentration of creative industries firms in the Zlín Region having low establishment costs and not having to conduct business at the local or regional level only due to using various communication technologies. Motion picture and video creative firms are poorly represented and concentrated only in the two major settlement centres in the region, i.e., Zlín and Uherské Hradiště, despite the presence of particular degree programmes at Tomas Bata University in Zlín and Film College in Zlín. Thus even the most populated MEPs with the largest urban agglomerations in the region do not provide sufficient proximity to customers together with limited local buzz.

The results of the mapping demonstrated the need for separate analyses of the two creative industries groups - enterprises with employees and non-employing enterprises particularly by the length of trading and spatial distribution. The relation between business cycle and the start up frequency of non-employing enterprises was indicated when their establishment follows the distinct stages of the business cycle with the highest increase in the peak of economic expansion and conversely the lowest increase in the final phase of the recession. The uniform distribution of the length of trading of enterprises with employees should be the subject of further research at the inter-regional level of the Czech Republic so that the interim specific feature of the Zlín Region could be generalized and related to the three defined types of creative industries segments by length of trading - aging, stagnant and emerging. Finally, the concentration of non-employing enterprises in the centre of the region is lower than the spatial concentration of the enterprises with employees with a closer relation to urbanization effects.

The database does not allow identifying and analyzing creative industries firms doing business in the Zlín Region with registered office (headquarters) outside the region, which reduces the explanatory power of the mapping results. Publicly available company databases in the Czech Republic offer only an indicative framework for evaluating number of employees in the creative industries with no possibility of their identification in accordance with the Creative Trident methodology importance and effectiveness.

\section{Acknowledgement:}

The authors are thankful to the project CreaClust - A Cross-border Cluster Initiative for the Development of Creative Industry No. 22410420020 for financial support to carry out this research. 


\section{References}

1. Baines, S. \& Robson, L. (2001). Being self-employed or being enterprising? the case of creative work for the media industries. Journal of Small Business and Enterprise Development 8(4), 349-362. http://dx.doi.org/10.1108/EUM0000000006830

2. Bell, D. \& Jayne, M. (2003). Assessing the role of design in local and regional economies. International Journal of Cultural Policy, 9(3), 265-284. http://dx.doi.org/10.1080/102866303200 0161696

3. Bell, D. \& Jayne, M. (2010). The creative countryside: policy and practice in the UK rural cultural economy. Journal of Rural Studies, 26(3), 209-218. http://dx.doi.org/10.1016/ j.jrurstud.2010.01.001

4. Bontje, M. \& Musterd, S. (2009). Creative industries, creative class and competitiveness: expert opinions critically appraised. Geoforum, 40(5), 843-852. http://dx.doi.org/10.1016/ j.geoforum.2009.07.001

5. Centre of Information and Statistics on Culture, National Information and Consulting Centre for Culture - NIPOS-CIK. (2011). Nipos adresáre. Retrieved from http://www.nipos$\mathrm{mk} . \mathrm{cz} /$ ?cat $=66$.

6. Cikánek, M. (2009). Kreativní průmysly: příležitost pro novou ekonomiku. Institut umění: Praha.

7. Garson, D. G. (2009). Multidimensional scaling: statnotes. Informally published manuscript, College of Humanities and Social Sciences, North Carolina State University, Raleigh, North Carolina. Retrieved from http://faculty.chass.ncsu.edu/garson/PA765/mds.htm.

8. Desrochers, P. \& Leppälä, S. (2011). Creative cities and regions: the case for local economic diversity. Creativity and Innovation Management, 20(1), 59-69. http://dx.doi.org/10.1111/j.14678691.2010.00586.x

9. Florida, R. (2002). The Rise of the Creative Class, and How It's Transforming Work, Leisure, Community and Everyday Life. Basic Books: New York.

10. Higs, P. \& Cunningham, S. ARC Centre of Excellence for Creative Industries \& Innovation (CCI). (2007). Australia's creative economy: mapping methodologies. Brisbane: Retrieved from http:// eprints.qut.edu.au/archive/00006228/

11. Higgs, P. \& Cunningham, S. (2008). Creative industries mapping: where have we come from and where are we going? Creative Industries Journal, 1(1), 7-30.

12. Higgs, P. \& Cunningham, S., Bakhshi, H. NESTA. (2008). Beyond the creative industries: mapping the creative economy in the United Kingdom. London: Retrieved from http://www.nesta.org. uk/publications/assets/features/beyond_the_creative_industries/

13. Jayne, M. (2004). Culture that works? creative industries development in a working-class city. Capital \& Class, 28(3), 199-210. http://dx.doi.org/10.1177/030981680408400119

14. Jayne, M. (2005). Creative industries: the regional dimension? Environment and Planning C: Government and Policy, 23(4), 537-556. http://dx.doi.org/10.1068/c0453

15. Jirčíková, E. (2009). Kreativní průmysl a jeho výkonnost. In Jirčíková E. (Ed.), Sborník příspěvků z mezinárodní vědecké konference Finance a výkonnost firem ve vědě, výuce a praxi (p. n). Zlín: Tomas Bata University. 
16. Kloudová, J. (2009). Kreativní ekonomika a její měření. Ekonomický časopis, 57(3), 247-262.

17. Kloudová, J. et al. (2010). Kreativní ekonomika: trendy, výzvy, př́ležitosti. Grada: Praha.

18. Lazzeretti, L., Boix, R. \& Capone, F. (2008). Do creative industries cluster? Mapping creative local production systems in Italy and Spain. Industry and Innovation, 15(5), 549-567. http:// dx.doi.org/10.1080/13662710802374161

19. Markusen, A. et al. (2008). Defining the creative economy: industry and occupational approaches. Economic Development Quarterly, 22(1), 24-45. http://dx.doi.org/10.1177/089124240 7311862

20. Pratt, A.C. (2008). Creative cities: the cultural industries and the creative class. Geografiska Annaler: Series B, Human Geography, 90(2), 107-117. http://dx.doi.org/10.1111/j.14680467.2008.00281.x

21. Rumpel, P., Slach, O., \& Koutský, J. (2010). Creative industries in spatial perspective in the old industrial Moravian-Silesian region. E+M Ekonomie a Management, 8(4), 30-46.

22. UNCTAD, United Nations. (2010). Creative economy report 2010. Geneva: Retrieved from http://www.unctad.org/Templates/webflyer.asp?docid=14229\&intItemID=5763\&lang=1\& mode $=$ downloads

23. Waitt, G. \& Gibson, C. (2009). Creative small cities: rethinking the creative economy in place. Urban Studies, 46(5\&6), 1223-1246. http://dx.doi.org/10.1177/0042098009103862

24. White, P. (2010). Creative industries in a rural region: creative West: the creative sector in the Western region of Ireland. Creative Industries Journal, 3(1), 79-88.

\section{Contact information}

RNDr. Pavel Bednár, PhD.

Tomas Bata University in Zlin, Faculty of Management and Economics

Mostni 5139, 76001 Zlin

Tel: +420576032848

E-mail:bednar@fame.utb.c\%.

Ing. Pavel Grebeniček

Tomas Bata University in Zlin, Faculty of Management and Economics

Mostni 5139, 76001 Zlin

Tel: +420576032992

E-mail:grebenicek@fame.utb.cz 